\title{
POSTCOLONIAL TRANSLATION STUDIES: FOREIGNIZATION AND DOMESTICATION OF CULTURE-SPECIFIC ITEMS IN OF MICE AND MEN'S INDONESIAN TRANSLATED VERSIONS
}

\author{
Hafizha Fitriyantisyam \\ e-mail: hfitriyantisyam@gmail.com \\ Aris Munandar \\ Universitas Gadjah Mada \\ e-mail: arismunandar@ugm.ac.id
}

\begin{abstract}
Resistance to Western Culture can be seen through translator's strategy of translating novels. This research aims to analyze the translation of culture-specific items in Indonesian translated versions of $O f$ Mice and Men, originally written by John Steinbeck. The selected translated versions belong to the work of Pramoedya Ananta Toer (2003) and Ariyantri E. Tarman (2017). The translations of culture-specific items are analyzed under Transnational American Studies paradigm to find out the dominant translation principle applied in both translated versions and the results are discussed from the perspective of postcolonial translation studies. From the data, it is found out that the domestication principle is more dominant than foreignization strategy. Analyzed from postcolonial translation studies, the tendency to use the domestication principle in translated novels show the efforts of the target culture to fight against Western culture as the source culture. Although both Indonesian versions of Of Mice and Men mostly apply the domestication principle, the recent translated version (T2) shows an increase in the use of foreignization principle in which English loanwords are frequently used. From a postcolonial translation studies' perspective, it can be concluded that target culture is against Western culture; however, the signs of cultural imperialism, especially linguistic imperialism, have grown in the recent years.
\end{abstract}

Keywords: culture-specific items; domestication; foreignization; postcolonialism; translation strategies

DOI $\quad:$ https://doi.org/10.22146/rubikon.v8i1.65478

Available at https://jurnal.ugm.ac.id/rubikon/article/view/65478

This work is licensed under a Creative Commons Attribution-ShareAlike 4.0 International License 


\section{INTRODUCTION}

Translation is understood as the act of transferring meanings and culture from the source text to the target text (Bassnett \& Lefevere, 1998). It means that a translator carries a responsibility to transfer a source text into a target text as precisely as possible. Translating a text is inseparable from translating a culture because culture is contained within a language and when a language is translated, the culture might be presented in the translated version depending on the translator's choice. The evidence that culture is also translated alongside the text can be seen from the way a translator translates the source text's culture-specific items. Baker (1992) defines culture-specific items as objects that are culturally tied to a certain culture, which can appear as abstract or concrete concepts, religious beliefs, social customs, and types of food. Culture-specific items have a wide range of categorizations, including ecology, material culture, social culture, organizations, customs, activities, procedures, concepts, gestures and habits, and slang (Newmark, 1988; Espindola \& Vasconcellos, 2006; Chung-ling, 2010).

Translating culture-specific items can be a challenging task for the translator. One reason is caused by the unavailable of equivalents in the target culture. Another reason is caused by the status of language that is held by the source and the target language. The statuses can be divided into a dominant language and a dominated language. A language is dominant if it is learned; spoken; and used internationally. English is one of the dominant languages. Otherwise, a language that is less known internationally is considered as a dominated language. Translation plays an important role in bridging the dominant and dominated language. For instance, the shortage of literary works in South Africa in the 1950s led the African translators to translate English literary works to improve their literature (Mlonyeni \& Naudé, 2004). One can see the positive side of translation from the previous case. However, postcolonial scholars have cautioned regarding the negative side of translation that may harm the dominated culture. According to Bassnett (1996), postcolonial theorists acknowledge the exploration of power within the translation. There is power inequality between the source text and the target text because of the status of the language.

Researches that combine translation studies and postcolonialism are not new. Several previous studies had observed this topic and object. For instance, Čerče (2017) conducted research that analyzes the translation process of working-class language in Of Mice and Men. The working-class language refers to the vernacular English that was spoken by poorly educated characters in the novel. The results show that the vernacular English was changed into formal vocabularies in the Slovene language. Čerče (2017) suggested translators should stick to linguistic and cultural nuances of the original text to preserve the characters' traits and allow the target readers to get a sense of the vernacular language of the original text. Another research was conducted by $\mathrm{Hu}$ and Shi (2015) who explored the translation of Chinese literary work into English by Buck and Saphiro and how their translations were seen from a postcolonial perspective. From the postcolonial point of view, Buck's translation is an example of resistance over cultural imperialism since he faithfully followed the 
original text. On the other hand, Saphiro's translation tended to blend the Chinese and English languages without ditching the meanings of original texts. It can be concluded that Saphiro did not only 'copy' the original text, but he also recreated new texts through translation $(\mathrm{Hu} \& \mathrm{Shi}, 2015)$. Thus, the recent research attempts to fill in the gaps in which the translation of culture-specific items in Indonesian versions of Of Mice and Men from a postcolonial perspective has yet to be explored.

This research aims to analyze the power inequality in translation, as seen from a postcolonial translation studies. The material objects are American novel Of Mice and Men by John Steinbeck and its Indonesian translations. This novel has been translated into several Indonesian versions and this research uses the first version by Toer (T1) and the most recent version by Tarman (T2). The first version was published in 2003 by Lentera Dipantara publisher; meanwhile, the recent version was published in 2017 by Gramedia Pustaka Utama. The consideration of choosing these two versions is based on their publication years. Both versions were published fourteen years apart. Since language is dynamic and develops over time (Harya, 2016), the patterns of language development can be observed and it helps discover the trends of the language used in a literary work.

This research is under the Transnational American Studies paradigm that observes the effects of American culture on a nation beyond the western hemisphere. According to Kim and Robinson (2017), the application of the Transnational American Studies paradigm is commonly applied to studies with themes related to colonial, imperial, and postcolonial; which are relevant from the slavery era to the modern era. In this research, the focus is set on the postcolonial perspective that explores the power relation between the United States and Indonesia through translation works.

This research uses the theory of translation principles by Venuti. Venuti (2001) divides translation principles into two types: foreignization and domestication. According to Venuti (1995), applying foreignization sends the reader abroad, and this principle values the linguistic and cultural differences that appear in the foreign texts. In short, this principle allows the target readers to be acquainted with the source culture. On the other hand, there is the domestication principle that is the otherwise of foreignization principle. According to Yang (2010), domestication adopts fluent style translation that minimizes the strangeness of foreign terms that makes domestication is more reader-oriented than foreignization. The focus of the domestication principle is to make the translation reader-friendly and natural. However, the downside of the domestication principle is the translated version might appear unnatural if the translator does not select the equivalent wisely. Besides foreignization and domestication, there is an additional principle named mixed strategies (Judickaitè, 2009). This principle serves two or more translation strategies in translating one term. The mixture can take place between the foreignizationforeignization continuum and the opposite foreignization-domestication continuum.

The translation strategies in this research follow the classification of translation strategies by Judickaite (2009) described as follows: 


\section{Foreignization Principle}

- Preservation strategy: the original terms are preserved without any changes because of unavailable of equivalents.

- Addition: the translator puts additional information related to the translated items within the text or in the footnotes.

- Naturalization: the items or terms experience changes morphologically or phonologically that follow the pronunciation in the target culture.

- Literal translation: the items or terms are translated in literal ways, which is highly likely to be translated word-by-word.

\section{Domestication Principle}

- Cultural equivalent: a translation strategy that alters the source language's terms to suit the culture of the target readers.

- Omission: this translation strategy omits a source culture's term in the translated version.

- Globalization: the translated version uses a more general term to translate the source text's culture-specific item.

- Translation by a more concrete word: it is also called localization in which the source culture's item is translated into something specific in the target culture's language.

- Creation: it is similar to free translation in which the translator has the freedom to translate a term that might not directly relate to the original text.

- Equivalent: this translation strategy is applied when both source text and target text have similar equivalents.

In general, the foci of postcolonial critics are to promote and celebrate diversity while shielding themselves from the influence of Western culture (Barry, 2002). From a postcolonial perspective, translation can be seen as a double-edged sword that can promote the dominated culture or promote imperialism. Tymoczko (2014) mentions this issue in her book, "...Conversely, when the translation is done by the colonized subjects themselves, the possibility of gathering and creating information can be turned to powerful ends, including counterespionage, conspiracy, and mutiny, leading to self-definition and selfdetermination..." (Tymoczko, 2014, p. 294). In other words, the status of language that becomes the source text and which translation principle frequently applied by the translators should be taken into consideration before concluding whether the translation is used to promote imperialism or to challenge it.

Linguistic imperialism is one of the elements of cultural imperialism that may result in the dominating force of English to other languages (Khodadady \& Shayesteh, 2016). Linguistic imperialism itself can be a danger that has the potentials to threaten the dominated cultures' social, religious, and cultural values (El-qassaby, 2015). By applying the domestication principle, the danger of linguistic imperialism can be minimized. It is the translator's decisions and efforts to make Western culture appear less noticeable in his/her translation. These views are in line with Tymoczko's views towards translation as a medium to express the dominated culture's self-determination and self-definition (2014) and Wang's argument (2009) in which the legacy of colonialism can be challenged and decolonized through translation.

In summary, the postcolonial translation studies focuses on power inequality that is contained in the source text and the target text. Translation can be regarded as a means of colonization or a means to resist colonization 
(Tymoczko, 2014). The view can differ based on which culture is the source text. Jacquemond (1992, as cited in Naudé, 2005) hypothesizes that a translation activity from the dominant culture to a dominated culture is more likely to apply the domestication principle over the foreignization principle. Related to this hypothesis, postcolonial theorists also consider translation as a tool to decolonize colonialism and strengthen the position of the dominated culture (Wang, 2009).

This research employs the descriptive qualitative method. Qualitative research allows the researcher to explore, identify, and interpret the recurring patterns that are found in the collection of data (Nassaji, 2015). Hence, the qualitative method is suitable for the research that concentrates on the patterns of culture-specific items translation in the research's objects. However, this research still applies to numbers in the process of collecting data as supplementary supports for the data analysis. The data of this research are taken from primary sources and secondary sources.

The primary sources of this research are taken from an American novel, of Mice and Men - originally written by John Steinbeck, which are translated into the Indonesian language by two Indonesian translators: Pramoedya Ananta Toer (T1) and Ariyanti E. Tarman (T2). The T1's version was published in 2003 by Lentera Dipantara publisher and the T2's version was published in 2017 by Gramedia Pustaka Utama.

The secondary sources consist of dictionaries, scientific journal articles, online news, and web articles that can support the process of classifying the translation strategies. Both English and Indonesian dictionaries are used in this research. For the English dictionary, the Merriam-Webster online dictionary is used to look up the English definitions of culture-specific items. For the Indonesian dictionaries, Kamus Besar Bahasa Indonesia (online) and Kamus Kata-Kata Serapan Asing dalam Bahasa Indonesia. Kamus Besar Bahasa Indonesia is used to find out the variety of meanings that are available in Indonesian terms. On the other hand, Kamus Kata-Kata Serapan Asing dalam Bahasa Indonesia is used to identify the origin of loan words in the Indonesian language that are not shown in Kamus Besar Bahasa Indonesia.

\section{DISCUSSION}

Based on the data, the total of culturespecific items found in the source text is 153 items. The detailed result can be seen in the following table.

\begin{tabular}{|c|l|c|c|}
\hline No & \multicolumn{1}{|c|}{ Categories } & $\begin{array}{c}\text { Numbers of } \\
\text { Data }\end{array}$ & Percentage \\
\hline 1 & Ecology & 19 & $12.4 \%$ \\
\hline 2 & Material Culture & 60 & $39.2 \%$ \\
\hline 3 & Social Culture & 27 & $17.7 \%$ \\
\hline 4 & $\begin{array}{l}\text { Organizations, Customs, Activities, } \\
\text { Procedures, and Concepts }\end{array}$ & 4 & $2.6 \%$ \\
\hline 5 & Gestures and Habits & 6 & $3.9 \%$ \\
\hline 6 & Slangs and Idioms & 37 & $24.2 \%$ \\
\hline \multicolumn{2}{|c|}{ Total } & 153 & $100 \%$ \\
\hline
\end{tabular}

Table 1. The classification of culture-specific items 
The data use the classification of culturespecific items by Newmark (1988) and its developments by Espindola and Vasconcellos (2006), and Chung-ling (2010). The culturespecific items are dominated by material cultured, followed by slang and idioms, social culture, ecology, gestures and habits, and organizations, customs, activities, procedures, and concepts. These culture-specific items are analyzed by Judickaite (2009) translation strategies. The comparisons of translation strategies applied by $\mathrm{T} 1$ and $\mathrm{T} 2$ can be seen as follows:

\begin{tabular}{|c|c|c|c|c|c|}
\hline \multirow{2}{*}{ No } & \multirow{2}{*}{ Translation Strategies } & \multicolumn{2}{|c|}{$\begin{array}{c}\text { Numbers of } \\
\text { Data }\end{array}$} & \multicolumn{2}{|c|}{ Percentage } \\
\hline & & $\mathrm{T} 1$ & $\mathrm{~T} 2$ & T1 & T2 \\
\hline \multicolumn{6}{|c|}{ Foreignization } \\
\hline 1 & Preservation & 8 & 16 & $5.2 \%$ & $10.5 \%$ \\
\hline 2 & Addition & 9 & 1 & $5.9 \%$ & $0.7 \%$ \\
\hline 3 & Naturalization & 7 & 18 & $4.6 \%$ & 11.7 \\
\hline 4 & Literal Translation & 20 & 8 & $13.1 \%$ & $5.2 \%$ \\
\hline \multicolumn{2}{|r|}{ Total } & 44 & 43 & $28.8 \%$ & $28.1 \%$ \\
\hline \multicolumn{6}{|c|}{ Domestication } \\
\hline 5 & Cultural Equivalent & 12 & 11 & $7.8 \%$ & $7.2 \%$ \\
\hline 6 & Omission & 9 & 3 & $5.9 \%$ & $1.9 \%$ \\
\hline 7 & Globalization & 27 & 23 & $17.6 \%$ & $15 \%$ \\
\hline 8 & Translation by a More Concrete Word & 9 & 11 & $5.9 \%$ & $7.2 \%$ \\
\hline 9 & Creation & 13 & 6 & $8.5 \%$ & $4 \%$ \\
\hline 10 & Equivalent & 31 & 47 & $20.3 \%$ & $30.7 \%$ \\
\hline \multicolumn{2}{|r|}{ Total } & 101 & 101 & $66 \%$ & $66 \%$ \\
\hline \multicolumn{6}{|c|}{ Mixed Strategies } \\
\hline 11 & Preservation - Equivalent & 4 & 6 & $2.6 \%$ & $4 \%$ \\
\hline 13 & Addition - Equivalent & 1 & 1 & $0.7 \%$ & $0.7 \%$ \\
\hline 14 & Addition - Cultural Equivalent & 2 & 2 & $1.2 \%$ & $1.2 \%$ \\
\hline 15 & Naturalization - Equivalent & 1 & 0 & $0.7 \%$ & $0 \%$ \\
\hline \multicolumn{2}{|r|}{ Total } & 8 & 9 & $5.2 \%$ & $5.9 \%$ \\
\hline
\end{tabular}

Table 2. Overall translation strategies

Based on the data, the dominant translation principle applied by both translators is the domestication principle. It means the translators change the source text's culture-specific items into objects that are more familiar to the target readers. According to Yang (2010), the presence of foreignness is minimized in the domestication principle to make the translation reader-friendly. It is reflected in the word choices in the domestication principle. For instance, T1 translates the sheriff into kepala polisi. This occupation, which is in the social culture category, is translated by the cultural equivalent strategy. A sheriff is one of the law enforcement agencies in the United States that is in charge of securing territory from criminalities. According to the International Association of Chiefs of Police (2018), the law enforcement agencies in the United States consist of local police, state police, special jurisdiction police, and deputy sheriff. In the target language, law enforcement is performed under a single main agency, which is the Indonesia National Police. Since the occupation as a sheriff does not exist in the target language, it is replaced by polisi that has 
similar responsibilities and job desks to a sheriff.

The foreignization principle is in the second place after the domestication principle. This principle attempts to introduce the foreign culture into its target readers. Even though both translators almost score the same number in foreignization, the translators favor different translation strategies. T1 prefers using literal translation; on the other hand, T2 prefers using naturalization strategy. The example of $\mathrm{T} 1$ using literal translation can be seen from the way he translates food, for instance, hot cake is translated into kue hangat. Hot cake refers to the United States' cuisine that resembles modern pancakes. According to Goldstein (2015), the term hot cake was first mentioned by Pennsylvania governor's letter, which referred to a cuisine of Native Americans. The generalized concept of a hot cake as a pancake begun in the mid-nineteenth century in which commercial baking powder became available in the market and thick-layered pancakes started becoming American's favorite (Goldstein, 2015). Therefore, a hot cake has its history in American culture. Indonesian readers in the 1950s might not be familiar with this food. To overcome the translation difficulty, the literal translation is applied in this part. Kue hangat, in this context, can be perceived as traditional snacks in the Indonesian language. On the other hand, T2 favors the naturalization strategy, which means it is more likely to find loanwords in her translation work. Some loanwords that she chooses have equivalents in the Indonesian language; however, the equivalent is not as popular as the loanword. For instance, T2 translates cream into krim. The Indonesian language has the equivalent of cream, which is kepala susu as in how T1 translates cream. However, the term kepala susu might appear unfamiliar to the young readers since the term krim is more frequently used in daily conversation in the present day.

The principle that gets the least total is mixed strategies. According to Judickaite (2009), mixed strategies are a combination of two or more translation strategies. For instance, the terms that are translated by preservation - equivalent strategy usually preserve the proper noun and translate the noun, for instance, Stetson (proper noun) and hat (noun) are translated into topi (noun) Stetson (proper noun). Another example is addition - equivalent that inserts additional information besides using its equivalent. It can be found in the translation of a horseshoe game in which the first translator inserts external addition in the footnote meanwhile the second translator includes the verb lempar (throw) within the text that describes the way the game is played.

\section{Postcolonial Translation Studies: Looking Beyond Translation Principles}

The results show that $66 \%$ of culturespecific items in the original novel are domesticated, followed by the application of foreignization principle $28.8 \%$ (T1) and $28.1 \%$ (T2), and mixed strategies $5.2 \%$ (T1) and 5.9\% (T2). Such wide gaps in the application of translation principles are examined from the postcolonial perspective that concerns the power relation between dominant and dominated culture. The findings show correlations to Tymoczko's views (2014) in which translation is done by the dominated culture can appear as a powerful mutiny toward Western domination and it leads to the target culture's self-definition and selfdetermination. The dominant use of domestication principle in this research reveals 
that the translators attempt to preserve their target culture's norms, which is in line with Tymoczko's argument (2010) in which domestication can induce equality in cultural exchange between a dominant and dominated culture. Nevertheless, the results gained from both versions show that linguistic imperialism makes some progress in penetrating the target language in the recent version, which is indicated by the second translator's choice to use preservation and naturalization strategy for terms that have equivalents in the target language.

\section{Bringing a Sense of Familiarity to the Target Readers}

One of the translators' attempts to bring a sense of familiarity is by localizing the source text's culture-specific items. It can be seen in the cultural equivalent strategy in which the source text's culture-specific items are replaced by terms that are well known by the target readers. For instance, the alterations of ecology category mostly apply the cultural equivalent strategy. It is known that some plants and animals are culturally bound to a certain culture, which means the same species can be rarely found in another culture. Both translators solve this translation difficulty by referring to the closest family of plants and animals that can be found in the target text. For instance, a coyote is translated into serigala (wolf) by the first translator; deer is translated into kijang (antelope) by the second translator. Considering coyote is native to North America, the same species might not be known by the target readers. The animal similar to a coyote in terms of its characteristics is represented by a wolf in the target language since the wolf is more recognizable among the target readers.
The same case appears in the translation of deer into kijang in which kijang is one of the native species of deer in Indonesia. The decision to find animals that share similarities to the source text's culture-specific items can ease the target readers' reading experience. Another example is the alteration of measuring systems. The second translator changes all the United States' measurement systems into Indonesian's measurement systems. Mile, pound, and acre are transformed into kilometer, kilogram, and hektar. The second translator not only translates the units, but she also converts the units. For instance, a quartermile is translated into 500 meter. It is a careful consideration to change the foreign measurement units to the target readers' customary.

\section{Resisting the West's Ideology and Challenging Imperialism}

Based on the findings, the domestication principle resists orientalism, which is commonly found in the first translator's work. The resistance towards orientalism is reflected through the way the first translator changes the religious terms in his translation. The religionrelated item is presented as follows:

ST: "Jesus Christ, you're a crazy bastard!" (Steinbeck, 1994, p. 12)

TT: "Ya, Rasul. Betul-betul haram jadah kau ini!?" (Steinbeck, 1994/2003, p. 10)

The first translator domesticates the source text by applying an equivalent strategy in which the term Jesus Christ is translated into Rasul (prophet). The example of Jesus Christ in this context does not refer to the actual Jesus; the example above is counted as an interjection that expresses disappointment. However, the expression itself is closely related to Christianity. The first translator decides to change it into Rasul, which is closer 
to the Islamic term in the target culture's customary. The second translator also domesticates the religion-related term, even though she applies a different translation strategy. The example can be seen as follows:

ST: "Jesus Christ, you're a crazy bastard!" (Steinbeck, 1994, p. 12)

TT: "Ya Tuhan, kau keparat sinting!" (Steinbeck, 1994/2017, p. 11)

The second translator's word choice is more general since she applies the globalization strategy. Jesus is acknowledged as the Son of God by Christians and the target culture only has one closest expression, in the general sense, which has a similar effect to Jesus Christ that is $Y a$ Tuhan. The word choices that are picked by both translators might be influenced by the fact that Islam is the largest religion in Indonesia, which means the chance their translation works being read by Muslims, is big as well. The translators either choose to change the term by using an appropriate term used by the majority religion or making Christianity less noticeable by generalizing the term in the target text. Thus, the translators cover the sense of Christianity in the original novel by applying the domestication strategy. They incline to maintain the ideology that is followed by the majority in the target culture. In this research, Christianity, which is shown in an expression form, is rejected by changing it into Islamic and general form.

\section{Protecting the Target Culture's Norms}

Taboo slangs do not belong only to Western societies. Indonesia also has taboo slang that is used on informal and limited occasions. The problem arises when the taboo slangs make an appearance in published books that are bought and read by the community. The translators have to decide whether they should include the Western's taboo slangs or omit them in the books by taking into account the opposite norms and values that both cultures hold. In this research, the translators decide to minimalize the apparent appearance of the Western's taboo slangs in their works. For instance, the translators rely on a creation strategy that enables them to cover up the true meanings of the source text's slang. Both translators apply the creation strategy to translate the term flop that refers to sexual intercourse. T1 translates it into bersenangsenang yang lebih tinggi and T2 translates it into main-main. Both translators avoid choosing the equivalent of a flop in the target text. Such activity is considered indecent from the perspective of the target culture. Then, the translators create new phrases that can lead the target readers' interpretation of flop to its intended meaning yet the translators make it less obvious.

\section{Foreignization Principle as Threats to Linguistic Imperialism}

The data show that the numbers of preservation and naturalization strategy in the 2017 version (T2) are doubled compared to the 2003 version (T1). The comparison of naturalization strategy can be seen as follows: 


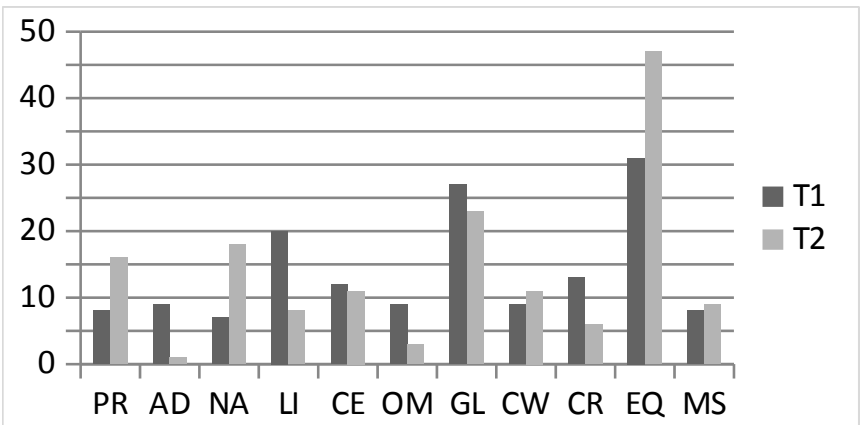

Figure 1. The application of translation strategies in Of Mice and Men's culture-specific items

Based on the graphic above, some translation strategies applied in both translated novels experience drastic changes over time, for instance, preservation strategy, addition, naturalization, literal translation, omission, creation, and equivalent strategy. It is noteworthy that the year when the novels were translated affects the trends of choosing translation strategies. For instance, when alfalfa had not yet developed in Indonesia, the first translator who worked on the translation in the 1950s applies the omission strategy.

In the comparison of preservation strategy, the preferences of both translators are obvious. The first translator chooses to localize the culture-specific items; however, the second translator preserves the source text's culture-specific items. It can be assumed that the second translator is adopting some parts of American culture in her translation, for instance, the preservation of sir, mister, and ma'am in which these terms have equivalents in the target text, as presented in the first translator's work. The second translator also tends to naturalize English items that have equivalents in the target language, for instance, cream and circus. The first translator chooses the items' equivalents that are included in Kamus Besar Bahasa Indonesia, which are kepala susu for cream and kumidi for circus; though it has to be admitted the equivalents are rarely used nowadays. On the other hand, the second translator chooses popular terms that fit into the present day's preference, which are mostly naturalized from the source language.

The application of naturalization in the most recent novel indicates that many English words have been naturalized into the Indonesian language and the words are used widely in Indonesian conversation. According to Judickaite (2009), this translation strategy does bring the target readers closer to the source culture since the original culturespecific items have been modified morphologically and phonologically. By analyzing the comparison between $\mathrm{T} 1$ and $\mathrm{T} 2$ in terms of the application of the foreignization principle, it can be concluded that the foreign items within the original text are more preserved in the recent novel.

Another pattern that can be found from the data is the second translator also applies a naturalization strategy to translate items that are culturally bound to American cultures, such as 'coon, jeans, boots, and solitaire. On the other hand, the T1 prefers generalizing the items in the target text. These findings indicate that Indonesians, as the target readers, have grown to be more accustomed to American culture compared to fourteen years ago when the first translation of $O f$ Mice and Men was published. The familiarity with American 
culture can result from the intensity of cultural contacts between Indonesia and America through the massive globalization wave in the recent years. Thus, the more familiar the target readers with American culture, the more they become familiar with its language. The strong force of English to the Indonesian language in this case can be considered as a part of linguistic imperialism as mentioned by Khodadady and Shayesteh (2016). The linguistic imperialism is unavoidable to grow in a globalizing era, which is proven by the more frequent applications of preservation and naturalization strategy in the recent translation. The growing number in the application of loan words can indicate the familiarity of the target readers toward the source culture has also increased; meaning the exposure of American culture in the target culture is strong. Thus, it can be assumed that English linguistic imperialism makes its progress to invade the target culture in incremental but yielding steady progress.

Historically speaking, the encounter of Indonesians and English language was traced back in 1914 when English was first taught in junior high schools (Lauder, 2008). During the colonization era, only Dutch children and the privileged class of Indonesians had an access to education. Thus, English was used in a limited setting and it was not considered as a medium of communication in Indonesia. Based on this history, it is arguable why T1, who started working on the translation of $O f$ Mice and Men in 1950, was inclined to domesticate culture-specific items that were culturally bound to American culture, for instance bar, raccoon, and sheriff. Instead of preserving the items in their original form, T1 avoided the appearance of foreign items that might cause confusion to the target readers whose familiarity with English were deficient.
In this case, it can be concluded that the power of English was not strong at the time the T1 translated the novel since the majority of Indonesian readers were still unfamiliar with English language and American culture.

The improvement of English's power in Indonesia was influenced by the emergence of America as the world economic superpower in the beginning of 20th century (Lauder, 2008). Since gaining its new status, the intensity of learning and speaking English has been increasing globally, including in Indonesia. This also strengthens the position of English as a dominant language. One of potentials of English that is acknowledged by Indonesian scholars is its function as a source of vocabulary for development and modernization of Indonesian language (Lauder, 2008). It can be seen from T2's translation in which loanwords from English are often used in her translation, for instance phonograph - fonograf and jeans - jins. Compared to the first translator's case, the use of English in Indonesia has become more common at the time $\mathrm{T} 2$ worked on the translation of Of Mice and Men. The power of English in Indonesia has also become stronger.

The constant exposure of Western culture through language has become a concern among Indonesian scholars. According to Alwasilah (1997), the Western culture, which is liberal, may bring bad influences or bad examples on Indonesian culture. The novel used in this research is an American product that contains cultural objects as reflected from the idiom and slangs in the dialogue, material objects, and social life. The characters are portrayed as uneducated people and they talk in offensive language. Their conversations are most likely related to sensitive issues such as prostitution and illegal activities. This is one of 
the portrayals of American culture during the Great Depression era. When this product is translated for the consumption of Indonesian readers, the translators act as the filters that select which items that need to be adjusted to suit the norms and values prevailing in Indonesia. Their efforts are seen from the way they neutralize the translation of terms related to prostitution or derogatory terms. From postcolonial perspective, it can be seen as an attempt to prevent the entry of Western culture that is incompatible with Indonesian culture.

\section{CONCLUSION}

Translation studies and postcolonial studies are proven to go hand-in-hand in this research. These fields are interconnected and give insight that colonialism does not end at the time the physical wars ended. A similar invasion process coming from a dominant culture is wrapped in a new different layer called postcolonialism.

The translation principle that stands out based on the findings is the domestication principle, which is target reader-oriented. The result is in line with the hypothesis of Jacquemond's argument (1992, as cited in Naudé, 2005) in which the translator who comes from a dominated culture tends to bring the foreign text closer to the target readers' familiarity. Even though the domestication principle is the most dominant, all translation strategies by Judickaite (2009) within the foreignization, domestication, and mixed continuum are found in both translation works.

In postcolonial translation studies, the dominated culture that translates the dominant culture's literary work tends to domesticate the source text's culture-specific items as a mechanism to resist the domination of Western power. Related to this research, American culture that is reflected from Of Mice and Men is adjusted by Indonesian translators in their translation works. The adjustments can be seen from the translation strategies that the translators applied to culture-specific items related to sensitive issues in the target text, such as the practice of sexual activity and jobs related to it. By analyzing two translation works that are originated from the same novel, the changes in preferred translation strategies could be seen. Even though both translators apply equivalent strategy the most, it is found out that the recent translated version of $O f$ Mice and Men applies more preservation and naturalization strategy than the oldest translation work does. In other words, the presence of American culture is a bit stronger in the recent translated version compared to the first translated version. The use of loan words from English in the recent translated version shows the progress of linguistic imperialism in the target culture.

\section{REFERENCES}

Alwasilah, A. C. (1997). Imperialisme bahasa dan budaya. In H. Alwa \& D. Sugono (Eds.). Politik, bahasa, dan pendidikan (pp. 8-11). Remaja Rosdakarya.

Baker, M. (1992). In other words: A course book on translation. Routledge.

Barry, P. (2002). Beginning theory: An introduction to literary and cultural theory. Manchester University Press.

Bassnett, S. (1996). The meek or the mighty: Reappraising the role of the translator. In R. Álvarez and M. C. Vidal (Eds.), Translation, power, subversion (pp. 1024). Multilingual Matters.

--- \& Lefevere, A. (1998). The translation turn in cultural studies. In S. Bassnett and A. Lefevere (Eds.), Constructing cultures: Essays on literary translation (pp. 123140). Multilingual Matters. 
Čerče, D. (2017). Between translation and transformation: Recreating Steinbeck's language in $O f$ Mice and Men. The Translator, 23(1), 67-82. https://doi.org/10.1080/13556509.2016.1 183092.

Chung-ling, S. (2010). Ideological interference in translation: Strategies of translating cultural references. Translation Journal, 14(3).

https://translationjournal.net/journal/5 3culture.htm.

El-qassaby, H. K. (2015). Linguistic imperialism and reshaping the world's new identity: A research paper in linguistics. International Journal of Language and Linguistics, 3(2), 61-68. https://10.11648/j.ijll.20150302.14

Espindola, E., \& Vasconcellos, M. L. (2006). Two facets in the subtitling process: Foreignisation and/or domestication procedures in unequal cultural encounters. Fragmentos, 30, 43-66. https://doi.org/10.5007/fragmentos.v30i 0.8205.

Goldstein, D. (2015). The oxford companion to sugar and sweets. Oxford University Press.

Harya, T. D. (2016). Language change and development: Historical linguistics. Premise Journal, 5(1), 103-117. https://doi.org/10.24127/pj.v5i1.418.

Hu, W., \& Shi, Z. (2015). A Postcolonial perspective on the cultural translation strategies: A case study of the English version of Shuihuzhuan (All Men are Brothers). Theory and practice in language studies, 5(3), 581-589. http://dx.doi.org/10.17507/tpls.0503.18.

International Association of Chiefs of Police. (2018). Types of law enforcement agencies.

https://www.discoverpolicing.org/explor e-the-field/types-of-law-enforcementagencies/
Judickaitè, L. (2009). Analysis of closed Lithuanian subtitles in cartoons the Wild, Ratatouille, and Over the Hedge. [Master's thesis, Vytautas Magnus University]. Vytautas Magnus University Library. https://vb.vdu.It/object/elaba:1791644/

Khodadady, E., \& Shayesteh, S. (2016). Cultural and linguistic imperialism and the EIL movement: Evidence from a textbook analysis. Educational research, 26(4),

604-622.

http://www.iier.org.au/iier26/khodadad y.pdf

Kim, S., \& Robinson, G. (2017). Introduction: Transnational American Studies in the "Age of Trump". Journal of Transnational American Studies, 8(1). 114.

https://escholarship.org/uc/item/7xb153 $\underline{\mathbf{v V}}$

Lauder, A. (2008). The status and function of English in Indonesia: A review of key factors. Makara seri sosial humaniora, 12(1). 9-20. https://media.neliti.com/media/publicati ons/4391-EN-the-status-and-functionof-english-in-indonesia-a-review-of-keyfactors.pdf

Mlonyeni, S. G., \& Naudé, J. A. (2004). Enriching Xhosa culture: The transference of social and material culture in the isiXhosa translation of the prisoner of Zenda. Alternation, 11(2), 247-263. https://journals.co.za/content/alt/11/2/A JA10231757 347

Nassaji, H. (2015). Qualitative and descriptive research: Data type versus data analysis. Language teaching research, 19(2), 129132.

https:doi.org/10.1177/136216881557274 $\underline{7}$

Naudé, J. A. (2005). The shaping of cultural knowledge in South African translation. Stellenbosch Papers in Linguistics, 36(1), 35-58. https://doi.org/10.5774/36-0-11 
Newmark, P. (1988). A textbook of translation. Longman.

Steinbeck, J. (2003). Tikus dan manusia (P. A. Toer, Trans.). Lentera Dipantara. (Original work published 1994).

---. (2017). Of mice and men: Tikus dan manusia (A. E. Tarman, Trans.). PT. Gramedia Pustaka Utama. (Original work published 1994).

Tymoczko, M. (2014). Metametonymics. In M. Tymoczko, Translation in postcolonial context: Early Irish literature in English translation (pp. 278-300). Routledge.

Venuti, L. (1995). The translator's invisibility: A history of translation. Routledge.

Venuti, L. (2001). Strategies in translation. In M. Baker (Ed.), Routledge encyclopedia of translation studies (pp. 240-244). Routledge.

Yang, W. (2010). Brief study on domestication and foreignization in translation. Journal of Language Teaching and Research, 1(1), 77-80. 10.4304/jltr.1.1.77-80.

Wang, H. (2009). Postcolonial approaches. In M. Baker, \& G. Saldanha (Eds.), Routledge encyclopedia of translation studies (pp. 200-2004). Routledge. 